British Political Facts Since 1979 
Also by David Butler

TWENTIETH-CENTURY BRITISH POLITICAL FACTS 1900-2000

THE BRITISH GENERAL ELECTION OF 1951

THE ELECTORAL SYSTEM IN BRITAIN 1918-1951

THE BRITISH GENERAL ELECTION OF 1955

THE STUDY OF POLITICAL BEHAVIOUR

ELECTION ABROAD (editor)

THE BRITISH GENERAL ELECTION OF 1959 (with Richard Rose)

THE BRITISH GENERAL ELECTION OF 1964 (with Anthony King)

THE BRITISH GENERAL ELECTION OF 1966 (with Anthony King)

POLITICAL CHANGE IN BRITAIN (with Donald Stokes)

THE BRITISH GENERAL ELECTION OF 1970 (with Michael Pinto-Duschinsky)

THE CANBERRA MODEL

THE BRITISH GENERAL ELECTION OF FEBRUARY 1974 (with Dennis Kavanagh)

THE BRITISH GENERAL ELECTION OF OCTOBER 1974 (with Dennis Kavanagh)

THE 1975 REFERENDUM (with Uwe Kitzinger)

COALITIONS IN BRITISH POLITICS (editor)

POLICY AND POLITICS (with A. H. Halsey)

THE BRITISH GENERAL ELECTION OF 1979 (with Dennis Kavanagh)

REFERENDUMS (with A. Ranney)

EUROPEAN ELECTIONS AND BRITISH POLITICS (with David Marquand)

DEMOCRACY AT THE POLLS (with H. Penniman and A. Ranney)

THE BRITISH GENERAL ELECTION OF 1983 (with Dennis Kavanagh)

DEMOCRACY AND ELECTIONS (with $V$. Bognador)

PARTY STRATEGIES IN BRITIAN (with Paul Jowett)

GOVERNING WITHOUT A MAJORITY

INDIA DECIDES (with Ashok Lahiri and Prannoy Roy)

THE BRITISH GENERAL ELECTION OF 1987 (with Dennis Kavanagh)

THE BRITISH GENERAL ELECTION OF 1992 (with Dennis Kavanagh)

ELECTIONEERING (with A. Ranney)

FAILURE IN BRITISH GOVERNMENT (with A. Adonis and T. Travers)

BRITISH ELECTIONS SINCE 1945

CONGRESSIONAL REDISTRICTING (with B. Cain)

THE BRITISH GENERAL ELECTION OF 1997 (with Dennis Kavanagh)

BRITISH POLITICS AND EUROPEAN ELECTIONS 1999 (with Martin Westlake)

THE BRITISH GENERAL ELECTION OF 2001 (with Dennis Kavanagh)

BRITISH POLITICS AND EUROPEAN ELECTIONS 2004 (with Martin Westlake)

THE BRITISH GENERAL ELECTION OF 2005 (with Dennis Kavanagh) 


\section{British Political Facts Since 1979}

David Butler

and

Gareth Butler 


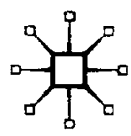

(c) David Butler and Gareth Butler 2006

Softcover reprint of the hardcover 1st edition 2006 978-1-4039-0372-3

All rights reserved. No reproduction, copy or transmission of this publication may be made without written permission.

No paragraph of this publication may be reproduced, copied or transmitted save with written permission or in accordance with the provisions of the Copyright, Designs and Patents Act 1988, or under the terms of any licence permitting limited copying issued by the Copyright Licensing Agency, 90 Tottenham Court Road, London W1T 4LP.

Any person who does any unauthorised act in relation to this publication may be liable to criminal prosecution and civil claims for damages.

The authors have asserted their rights to be identified as the authors of this work in accordance with the Copyright, Designs and Patents Act 1988.

First published in 2006 by

PALGRAVE MACMILLAN

Houndmills, Basingstoke, Hampshire RG21 6XS and

175 Fifth Avenue, New York, N.Y. 10010

Companies and representatives throughout the world.

PALGRAVE MACMILLAN is the global academic imprint of the Palgrave Macmillan division of St. Martin's Press, LLC and of Palgrave Macmillan Ltd. Macmillan ${ }^{\circledR}$ is a registered trademark in the United States, United Kingdom and other countries. Palgrave is a registered trademark in the European Union and other countries.

ISBN 978-1-4039-0373-0

ISBN 978-0-230-55476-4 (eBook)

DOI $10.1057 / 9780230554764$

This book is printed on paper suitable for recycling and made from fully managed and sustained forest sources.

A catalogue record for this book is available from the British Library.

A catalog record for this book is available from the Library of Congress.

$\begin{array}{llllllllll}10 & 9 & 8 & 7 & 6 & 5 & 4 & 3 & 2 & 1\end{array}$

$\begin{array}{llllllllll}15 & 14 & 13 & 12 & 11 & 10 & 09 & 08 & 07 & 06\end{array}$ 


\section{Contents}

Introduction $\quad$ xiv

I Ministries 1

Conservative Government 1979-90 1

Conservative Government 1990-97 8

Labour Government 1997- $\quad 12$

$\begin{array}{lr}\text { Ministerial Salaries } & 18\end{array}$

$\begin{array}{ll}\text { Opposition Salaries } & 19\end{array}$

Ministerial Offices 1979-2005 20

Holders of Ministerial Offices 1979-2005 22

Ministerial Statistics $\quad 26$

Biographical Notes $\quad 29$

Index of Ministers $\quad 32$

II Parties 46

$\begin{array}{ll}\text { Conservative Party } & 46\end{array}$

Party Leaders $\quad 46$

Conservative Party Leadership Elections $\quad 46$

$\begin{array}{ll}\text { Deputy Leaders } & 47\end{array}$

Leaders in the House of Lords $\quad 47$

Principal Party Officials $\quad 47$

Conservative Research Department $\quad 50$

Chief Whips in the House of Commons $\quad 50$

Chief Whips in the House of Lords 50

Chairmen of the 1922 Committee $\quad 50$

Conservative Shadow Cabinets $\quad 51$

Party Membership $\quad 51$

Party Finance $\quad 52$

Party Structure $\quad 52$

National Union of Conservative and Unionist Associations 52

Labour Party $\quad 53$

Party Leaders and Deputy Leaders $\quad 53$

Leadership Elections $\quad 53$

Leaders in the House of Lords $\quad 56$

Chief Whips in the House of Commons $\quad 56$

Chief Whips in the House of Lords $\quad 56$ 
Labour Party - National Executive Committee 56

Parliamentary Labour Party - Parliamentary Committee 58

$\begin{array}{ll}\text { Party Conferences } & 60\end{array}$

$\begin{array}{ll}\text { Party Membership } & 60\end{array}$

The Labour Party - Organisation and Constitutions 61

$\begin{array}{ll}\text { Sponsored M.P.s } & 62\end{array}$

Party Finance $\quad 62$

$\begin{array}{ll}\text { Liberal Party } & 63\end{array}$

$\begin{array}{ll}\text { The Alliance and the Merger } & 63\end{array}$

$\begin{array}{ll}\text { Leaders and Deputy Leaders of the Party } & 63\end{array}$

Leaders in the House of Lords $\quad 63$

$\begin{array}{ll}\text { Principal Office-holders } & 63\end{array}$

Chief Whips in the House of Commons 64

Chief Whips in the House of Lords 64

Annual Conferences 1979-88 64

(Social and) Liberal Democrats $\quad 64$

Leaders and Deputy Leaders of the Party 64

$\begin{array}{ll}\text { Principal Office-holders } & 65\end{array}$

$\begin{array}{ll}\text { Party Conferences } & 65\end{array}$

$\begin{array}{ll}\text { Party Finance } & 66\end{array}$

$\begin{array}{ll}\text { Minor Parties } & 66\end{array}$

Co-operative Party $\quad 66$

$\begin{array}{ll}\text { Green Party } & 66\end{array}$

$\begin{array}{ll}\text { Irish Parties } & 67\end{array}$

$\begin{array}{ll}\text { Alliance Party of Northern Ireland } & 68\end{array}$

$\begin{array}{ll}\text { Militant } & 69\end{array}$

The National Front and British National Party 69

$\begin{array}{ll}\text { Natural Law Party } & 70\end{array}$

$\begin{array}{ll}\text { Plaid Cymru (Welsh Nationalist Party) } & 70\end{array}$

$\begin{array}{ll}\text { Referendum Party } & 71\end{array}$

$\begin{array}{ll}\text { Scottish National Party } & 71\end{array}$

$\begin{array}{ll}\text { Social Democratic Party } & 72\end{array}$

$\begin{array}{ll}\text { United Kingdom Independence Party (UKIP) } & 73\end{array}$

$\begin{array}{ll}\text { Independent M.P.s } & 73\end{array}$

Minor Parties - Representation in the House of Commons 74

Other Minor Parties Contesting Parliamentary Elections 74

$\begin{array}{ll}\text { Political Pressure Groups } & 75\end{array}$

$\begin{array}{ll}\text { Registration of Political Parties } & 75\end{array}$

$\begin{array}{ll}\text { III Parliament } & 76\end{array}$

$\begin{array}{ll}\text { House of Commons } & 76\end{array}$

$\begin{array}{ll}\text { Speakers and Their Deputies } & 76\end{array}$ 
Officers of the House of Commons $\quad 76$

$\begin{array}{ll}\text { Parliamentary Sessions } & 77\end{array}$

$\begin{array}{ll}\text { Commons Hours of Sitting } & 77\end{array}$

Westminster Hall $\quad 77$

Emergency Recalls of the House of Commons $\quad 77$

$\begin{array}{ll}\text { Broadcasting of Parliament } & 78\end{array}$

Main Occupations of Members of Parliament

1979-2005 $\quad 79$

Education of Conservative and Labour M.P.s

House of Commons Business $\quad 80$

Fathers of the House of Commons $\quad 81$

$\begin{array}{lr}\text { Long-service M.P.s } & 81\end{array}$

$\begin{array}{ll}\text { Oldest and Youngest M.P.s } & 81\end{array}$

Family Connections of M.P.s $\quad 82$

$\begin{array}{ll}\text { Spouse's Succession } & 83\end{array}$

Filial Succession $\quad 83$

$\begin{array}{ll}\text { Dual Mandates } & 84\end{array}$

Critical Votes in the House of Commons since 1979

Government Defeats on the Floor of the House of Commons 1979- 85

Confidence Motions since $1979 \quad 85$

Guillotine and Programme Motions since $1979 \quad 86$

M.P.s' Suspension $\quad 86$

$\begin{array}{lr}\text { Select Committees } & 87\end{array}$

Chairmen's Liaison Committee $\quad 88$

Committee of Selection 1840- $\quad 88$

Committee of Public Accounts, 1862- $\quad 88$

Public Accounts Commission, 1984- 88

Committee on European Secondary Legislation 1974-76;

European Legislation etc. 1976-98; European Scrutiny

Committee 1998- $\quad 89$

Procedure (Sessional) Committee 1976- 89

House of Commons Services Committee 1965-92 89

House of Commons Commission 1978- 90

Domestic Committees $\quad 90$

Other Committees $\quad 90$

Committee of Privileges c.1630-1995 91

Committee on Standards and Privileges 1995- 92

Parliamentary Commission for Standards $\quad 92$

Statutory Instruments 1947- 93

Committee on Parliamentary Commision for Administration 
Parliamentary Commissioner for Administration (Ombudsman) 94

$\begin{array}{ll}\text { Select Committees since } 1979 & 95\end{array}$

$\begin{array}{lr}\text { Payment of M.P.s } & 97\end{array}$

$\begin{array}{lr}\text { House of Lords } & 98\end{array}$

Lord Chairmen of Committees $\quad 98$

Officers of the House of Lords 99

Composition of the House of Lords 99

$\begin{array}{lr}\text { Creation of Peerages } & 100\end{array}$

Party Strengths in the House of Lords $\quad 100$

House of Lords Sittings and Business 101

Critical Votes in the House of Lords 102

Landmarks in the Reform of the House of Lords since $1997 \quad 103$

$\begin{array}{ll}\text { Royalty } & 104\end{array}$

Royalty and Politics 104

Private Secretaries to the Sovereign 105

$\begin{array}{ll}\text { Lord Chamberlains } & 105\end{array}$

$\begin{array}{ll}\text { Civil List of the Crown } & 105\end{array}$

Total Head of State Expenditure 106

$\begin{array}{lll}\text { IV Elections } & 107\end{array}$

$\begin{array}{ll}\text { General Election Statistics } & 107\end{array}$

$\begin{array}{ll}\text { General Election Results by Regions } & 110\end{array}$

$\begin{array}{ll}\text { Referendum on E.E.C. Membership } & 111\end{array}$

$\begin{array}{ll}\text { Party Changes between Elections } & 111\end{array}$

$\begin{array}{lr}\text { M.P.s' Changes of Allegiance } & 112\end{array}$

M.P.s Elected under New Label 114

M.P.s Denied Party Renomination 114

$\begin{array}{ll}\text { By-elections } & 116\end{array}$

Seats Changing Hands at By-elections 116

$\begin{array}{ll}\text { Notable Retentions of Seats in By-elections } & 117\end{array}$

M.P.s Resigning to Fight By-elections 118

$\begin{array}{lr}\text { Electoral Administration } & 118\end{array}$

Redistribution $\quad 119$

Election Expenses $\quad 119$

$\begin{array}{lr}\text { Central Party Expenses } & 120\end{array}$

Lost Deposits $\quad 120$

Women Candidates and MPs 1974-2005 121

Election Petitions and Challenges 121

$\begin{array}{ll}\text { Sources on Electoral Matters } & 121\end{array}$

Public Opinion Polls 122

Gallup Poll 122

National Opinion Polls (NOP) 122 
Marplan Ltd/ICM Research

Louis Harris Research Ltd/Harris Research Centre 123

Market \& Opinion Research International (MORI) 123

YouGov 124

$\begin{array}{ll}\text { Populus } & 124\end{array}$

Polling Archives $\quad 124$

Polls on Voting Intentions 124

Opinion Poll Accuracy in General Elections 132

$\begin{array}{ll}\text { V Civil Service } & 134\end{array}$

$\begin{array}{ll}\text { Heads of Departments and Public Offices } & 134\end{array}$

Salary of Permanent Secretary in the Civil Service 138

Prime Minister's Principal Private Secretary 138

$\begin{array}{ll}\text { Chief of Staff } & 138\end{array}$

$\begin{array}{ll}\text { Appointments Secretary } & 138\end{array}$

$\begin{array}{ll}\text { Prime Minister's Staff } & 138\end{array}$

$\begin{array}{ll}\text { Special or Political Advisers to Ministers } & 139\end{array}$

$\begin{array}{ll}\text { Size of Civil Service } & 140\end{array}$

$\begin{array}{ll}\text { Number of Civil Servants } & 140\end{array}$

$\begin{array}{lr}\text { Civil Service Agencies } & 142\end{array}$

Next Steps 142

$\begin{array}{ll}\text { VI Justice and Law Enforcement } & 148\end{array}$

Major Criminal Justice Legislation 1979- 148

Major Legislation Relating to the Administration of $\begin{array}{lr}\text { Civil Justice 1979- } & 150\end{array}$

$\begin{array}{lr}\text { Cases of Political Significance } & 150\end{array}$

Principal Judges $\quad 152$

Other Legal and Law Enforcement Officials 155

Royal Commissions, Committees of Inquiry and Tribunals 156

Investigatory Process 156

Royal Commissions $\quad 157$

Permanent and Operating Commissions 157

Departmental Committees 158

A Select List of Departmental Committees 158

(Political) Honours Scrutiny Committee 1924-2005 160

$\begin{array}{ll}\text { Intelligence Services } & 160\end{array}$

$\begin{array}{ll}\text { Security Commission } & 161\end{array}$

$\begin{array}{ll}\text { Number of Judges } & 161\end{array}$

The Growth of Judicial Review 162

Recorded Crime 1980-2004 163 
$\begin{array}{ll}\text { British Crime Survey 1981-2004 } & 164\end{array}$

England and Wales 164

$\begin{array}{ll}\text { Prison Population in England and Wales } & 165\end{array}$

Parole Board 1967- 166

$\begin{array}{ll}\text { Police Force } & 166\end{array}$

VII Population, Health and Employment 167

UK Population and Migration 1979- $\quad 167$

$\begin{array}{ll}\text { Geographical Distribution } & 168\end{array}$

Births, Deaths and Marriages in the UK 169

$\begin{array}{ll}\text { Causes of Death } & 169\end{array}$

$\begin{array}{ll}\text { Racial Composition of the UK Population } & 169\end{array}$

$\begin{array}{ll}\text { Education Spending - England and Wales } & 171\end{array}$

$\begin{array}{ll}\text { Maintained Secondary Schools by Religious Character } & 171\end{array}$

Pupils in Full-time Education (000s) England 172

$\begin{array}{lr}\text { Higher Education Statistics } & 172\end{array}$

$\begin{array}{lc}\text { Transport } & 173\end{array}$

$\begin{array}{ll}\text { Employment } & 176\end{array}$

Major Employment Legislation 176

Major Employment Litigation 177

Advisory Conciliation and Arbitration Service (ACAS) 1974- 178

Low Pay Commission 1997- 178

Disability Rights Commission $2000 \quad 178$

Earnings and Hours Worked 179

$\begin{array}{ll}\text { Labour Force } & 179\end{array}$

Employees in Employment by Industry 180

Trades Union Congresses 1900- 181

The Largest Unions 181

Membership of the Largest Unions 186

Unemployment, Industrial Disputes and Trade

$\begin{array}{ll}\text { Union Statistics } & 187\end{array}$

$\begin{array}{ll}\text { VIII The Treasury and the Economy } & 188\end{array}$

$\begin{array}{ll}\text { Some Landmarks in the British Economy } & 188\end{array}$

$\begin{array}{ll}\text { Sources of Government Economic Advice } & 190\end{array}$

Head of Government Economic Service (1964-) 190

Chief Economic Adviser to the Treasury (1999-2004) 191

Bank of England (1696) 191

Monetary Policy Committee of the Bank of England (1997) 191

National Economic Development Council (1961-92) 191

Commission on Pay Comparability (1979-80) 191

Council of Economic Advisers (1997-) 191 
Economic Interest Groups $\quad 192$

$\begin{array}{ll}\text { Select Statistics } & 193\end{array}$

Retail Price Index $\quad 193$

Inflation rate 193

Gross Domestic Product, Taxes and Prices 194

Production and Interest Rates 195

Base Rates of Major Clearing Banks 196

Government Borrowing and National Debt 197

Balance of Trade $\quad 198$

Central Government Revenue: Inland Revenue 198

Customs and Excise Duties, 1993- (£m) 199

Public Spending as a Percentage of GDP 199

UK Domestic Household Consumption Expenditure (£m) 200

Concentration of Marketable Wealth Among Adult Population 201

Shares of Total Income Tax Liability 202

$\begin{array}{ll}\text { Consumer Credit } & 202\end{array}$

Budget Dates 203

$\begin{array}{ll}\text { Privatisation 1979-97 } & 204\end{array}$

Nationalised Industries $\quad 208$

External Financing Requirements of Nationalised Industries 216

$\begin{array}{ll}\text { Regulators of Privatised Industries } & 217\end{array}$

Central Government Trading Bodies 220

$\begin{array}{ll}\text { Other Quasi-governmental Organisations } & 220\end{array}$

IX Devolution and Local Government 223

$\begin{array}{ll}\text { The British Isles } & 223\end{array}$

Scotland 223

Scottish Parliament Election $\quad 224$

$\begin{array}{ll}\text { Wales } & 225\end{array}$

Welsh Assembly Election $\quad 226$

Northern Ireland 1972- $\quad 227$

$\begin{array}{ll}\text { The Channel Islands } & 229\end{array}$

$\begin{array}{ll}\text { The Isle of Man } & 231\end{array}$

Devolution: Main Landmarks $\quad 231$

Local Government $\quad 232$

Structure $\quad 232$

Major Legislation Affecting Local Government 233

Local Authority Interest Groups 235

Local Government Elections 236

Local Government Elections 1973- 237

London Government $\quad 242$

National vote share in local elections 243 
Major Treaties and Documents Subscribed to by Britain since $1979 \quad 244$ International Organisations 244

World Bank and International Monetary Fund 245

United Nations (UN) 245

North Atlantic Treaty Organisation (NATO) 245

General Agreement on Tariffs and Trade (GATT) 245

World Trade Organisation (WTO) 245

G8 (G7) 245

British Ambassadors to Leading Powers 246

European Union 247

The European Union (Communities) 247

A Chronology of Events since 1979

Summits 251

Net UK Payments to European Community Institutions (£m) 252

European Parliament 252

Leaders of the British Party Delegations 253

Referendum on EEC Membership 254

Direct Elections to European Parliament 254

European Court of Justice 256

Non-EU European Organisations with British Membership 257

Commonwealth 260

Commonwealth Heads of Government Meetings, 1979- 260

Independent Self-Governing Members of the Commonwealth 260

British Colonies and Dependencies 261

Defence 263

Major Military Operations 263

$\begin{array}{ll}\text { XI The Media } & 268\end{array}$

The Press 268

National Daily Newspapers $\quad 268$

National Sunday Newspapers $\quad 270$

London Evening Newspapers 273

Partisan Tendencies and Circulations of National Daily

Newspapers in British General Elections 1979-2005 273

Partisanship in Elections $\quad 274$

Circulations of National Newspapers 274

Circulation of National Sunday Newspapers $\quad 274$

Provincial Morning Daily Newspapers $\quad 275$

Main Political Weeklies 275

The Press Council, 1953-90 276

Press Complaints Commission 1991- 277 
$\begin{array}{ll}\text { Broadcasting } & 277\end{array}$

$\begin{array}{ll}\text { British Broadcasting Corporation } & 278\end{array}$

$\begin{array}{ll}\text { BBC Radio } & 279\end{array}$

BBC Local Radio $\quad 280$

BBC Television $\quad 280$

Broadcast Receiving Licences and BBC Expenditure $\quad 281$

$\begin{array}{lr}\text { Independent Broadcasting } & 282\end{array}$

Independent Broadcasting Authorities $\quad 283$

Channel 3 - ITV Programme Contracting Companies 284

The ITV Network Centre $\quad 285$

$\begin{array}{ll}\text { Channel Four } & 285\end{array}$

S4C 286

Channel $5 \quad 286$

Cable Television $\quad 287$

Multichannel Television $\quad 288$

Channel Share of Viewing $\quad 289$

Independent Local Radio 290

Broadcasting Complaints Commission 1981-96 291

Broadcasting Standards Council 1988-96 291

Broadcasting Standards Commission 1997-2003 291

The Internet as a News Provider $\quad 291$

Inquiries into Broadcasting $\quad 292$

$\begin{array}{ll}\text { XII Political Allusions } & 293\end{array}$

$\begin{array}{lr}\text { Political Place-Names } & 293\end{array}$

Political Quotations $\quad 295$

Political Scandals $\quad 302$

Major Civil Disturbances and Demonstrations 303

Political Assassinations (Members of the House of Lords
or House of Commons)

$\begin{array}{lr}\text { Bibliographical Note } & 304\end{array}$

Internet Addresses 306

$\begin{array}{ll}\text { Index } & 310\end{array}$ 


\section{Introduction}

British Political Facts 1900-2000 was the eighth edition of a work started in 1960. It was an endeavour to set out in compact and accessible form the essential facts and statistics of recent politics. The book grew as more years were covered and as government became more complicated.

The time has come to start again. The twentieth-century volume will, it is hoped, stay in print. But a new approach is needed for the twenty-first century. In the pages that follow all the essential elements of the old work are preserved but often arranged in a new format. However new material and time series, not available to a work that tried to treat 1900 and 1999 equally, are offered here.

Government and Local Authorities now produce much more material about their activities - although some non-government organisations, notably the political parties, produce rather less. But the preparation of reference works has been transformed in recent years by the arrival of the internet. Scholars can now call up from their computers a vast body of data. The great bulk of the information in this book is publicly available on the internet, for those who know where and how to look. We have tried to include appropriate source references.

Because we are starting the book only in 1979, we have been able to include much new information which was not in the old book. The new British Political Facts records the share of GDP spent on health, and the percentage of schoolleavers going on to university. We now provide information about occupations of politicians in the index of ministers, for example, and much more detailed economic data - the book now sets out the rate of inflation in October 1988, and the growth rate in June 1992.

We have not been rigorously consistent on the starting date for this volume. In many cases we have included names and statistics relating to the period of the 1974-79 Labour Government, even though the rationale for the 1979 start date is of course the election of Mrs Thatcher as Prime Minister on 3 May. We took the view that few readers will be offended if we include a little extra information.

Many of the other rules which applied to previous editions have survived intact. We continue to confine ourselves to British material; although there is an expanded chapter on International Relations, our consideration of other countries is seen through the prism of British government policy. There is very limited international comparison in the social and economic statistics.

Equally, we confine ourselves to the Political. In the 1979-2005 period, we have taken the view that religious institutions played virtually no part in politics, and we have jettisoned that chapter (influenced, also, by the fact that the 
statistics on religious affiliations provided by different churches and faiths are extremely suspect, and not really comparable with each other). Monarchy has survived, but in a very limited form, appended to the Parliament chapter.

Facts remain sacrosanct. While we have doubtless made some mistakes, we have done our best throughout to confine ourselves to demonstrable fact. As far as possible we have tried to avoid making subjective judgements (although it is impossible to avoid them in the Allusions chapter). In the 1900-2000 book, some of the statistical time series were creaking with the effort to align the figures on a comparable basis over the whole century. The 1979-2005 statistics are much more robust, drawing as ever on the excellent Annual Abstract of Statistics and other Office of National Statistics publications.

In many areas the time frame of the new book allows us to adapt to the changing political agenda. Health and education statistics are improved, while the Commonwealth takes a less prominent place. Finding data on the use of the internet as a news provider has proved difficult, but it takes its place in the new Media chapter. In the Public Sector pages, now part of the Economy chapter, government regulators now take up more space than heads of nationalised industries - another sign of the times.

The old book was organised into four or five very meaty chapters at the front (which we believe were the most heavily used), and a long 'tail' of shorter and shorter chapters with less and less substance. Though very few sections have been lost - apart from Royalty and Religion, mentioned above - we have tried to rationalise the book into a smaller number of weightier chapters, while preserving the early chapters in much the same format. It makes sense to combine local government with devolution, for example, because the London Mayor sits squarely across both; and there is little logic to maintaining a distinction between Britain's relations with Canada or Australia (previously in the Commonweath chapter) and relations with France or Turkey (in the old International Relations).

In previous editions we have included acknowledgements to all the many librarians, scholars and others who have helped and advised us on compiling this book. We are starting again with a clean slate in 2005, so we hope those who have contributed to previous editions will forgive their omission from the acknowledgements this time. The House of Commons Library and the BBC's Political Research Unit remain the most invaluable sources of data. Much of their material already has at least limited public circulation but we are grateful for their help in enabling us to locate what we need. The government departments and political parties have been most helpful. Colleagues at Nuffield College, Oxford and particularly in the Nuffield College library have always been generously supportive. But we should end by thanking the many readers of past editions who have sent in corrigenda. Since error is inevitable in a work of this sort, may we urge them to continue in their friendly monitoring. 